\title{
Sustainable Tourism Concept to Revitalize Ocarina Area in Batam City, Indonesia
}

\author{
Helen Cia, I Gusti Ngurah Anom Gunawan, Hendro Murtiono \\ Universitas Diponegoro, Semarang, Indonesia \\ Corresponding e-mail: helencia0179@gmail.com
}

\section{Article info:}

Received: 19-04-2020, Revised: 23-05-2020, Accepted: 14-09-2020

\begin{abstract}
The purpose of this research is to explore the concept of revitalizing the coastal tourism area with a sustainable tourism approach. Ocarina area is one of the tourist destinations in Batam city. Its strategic location is right in the center of Batam and is surrounded by several areas with different functions, among others there are housing (housing Regata, housing Monde Residence, housing Avante, Monde Signature housing, etc.), a school (Mondial school), a commercial area ( Pasir Putih shops, Mahkota Raya shops) and also the location of Ocarina area is close to the international ferry. The phenomenon that occurs in this tourist area has long been built and managed but has decreased visitors so that needs to be revitalized by using the concept of sustainable tourism. This strategic location is not accompanied by the success of the development of the Ocarina area as a public space that offers a variety of game facilities and culinary venues. The phenomenon that makes the need for revitalizing measures both physically and economically to make the Ocarina area can attract visitors to come and enjoy the facilities that are in it. The research method was a qualitative method of direct observation in the field. Analysis process is conducted to identify the problems that exist in the field today especially in the area of Ocarina Phase 1 so that the area of Ocarina Phase 2 can make Ocarina Phase 1 to be revitalized area and can be one of the sustainable tourism Batam city that can improve the economy of Batam city.
\end{abstract}

Keywords: revitalization, sustainable tourism, visitor

\section{Introduction}

Ocarina area is a family fun area that also becomes one of the tourist destinations in Batam city. The area of Ocarina is located in an area with a total of \pm 60 hectares which besides as a playground area there is also a residential area (Monde Bay, Monde Residence, Monde Signature, Regata, Avante), the education area of the national Plus Mondial School, commercial area (Trikarsa Ekualita shops, Oriental shops, Monde Bay shops, Pasir Putih shops) and also there is a market facility that besides selling raw food ingredients and groceries also there is a area selling food and drinks that have been processed and ready to serve is called Pasir Putih market.

Revitalizing as one of the actions so that a region becomes a positive area again, the part of the city that used to be crowded with community activities then increasingly experienced setbacks and degradation.

The physical aspects and economic aspects of either the building or the city part is an important aspect when we will take the revitalizing action of an area. Physical revitalization means a short-term strategy in order to encourage increased long-term economic activity. Economic activity also needs to consider the socio-cultural aspects and environmental aspects (environmental objectives). The socio-cultural aspects and environmental aspects 
are needed so that with the proper utilization is likely to form a consistent maintenance and control mechanism in connection with the availability of city facilities and infrastructure.

This discussion uses the theory of revitalization, Kevin Lynch-Image of The City Theory and Sustainable Tourism theory where this theory learns about the physical or social significance of the particular region, its function, its history, or even from its name. This theory will review the question of the form that is seen and taken that in the form of actual design should be used to strengthen the meaning and always continue (sustainable). The physical image of an area can be seen and divided into 5 (five) element namely paths, edges, district, nodes and landmarks. The Sustainable Tourism concept was first introduced by the World Commission on Environment and Development (WCAD) on Brunlad Report in 1987 that, "Sustainable development is development that meets the needs of present without compromising the ability of future generation to meet their own needs" (in Abdilah Fitra and Leksmono, S Maharani, 2001). It is understandable that Sustainable Development is a part of sustainable development that considers the needs at this time by not neglecting the ability of future generations to meet its needs. Similarly, the WTO (World Trade Organization) emphasizes the principles of development that include, Ecological Sustainability; Social and Cultural Sustainability; And Economic Sustainability, both for the current generation and the future generations. In the course of time, the concept of sustainable building (sustainable Development) adopted the concept of sustainable tourism development (sustainable Tourism Development). Sustainable tourism development is regarded as a process of tourism development that is oriented towards the sustainability of resources needed for future development, the sense of sustainable tourism develoanompment is also interpreted "Form of tourism that are consistent with natural, social, and community values and which allow both host and guest to enjoy positive and worth while interaction and shared experience" (in the book Sustainable tourism in the Global whirlpools , 2010). Moreover, Anom, emphasizing sustainable tourism development not only on ecology and economics, but also sustainable cultures because culture is also an important resource in the development of tourism in the book “Pariwisata Berkelanjutan Dalam Pusaran Krisis Global” (Anom, 2010).

\section{Theory of Sustainable Tourism}

Sustainable Tourism (sustainable tourism) and sustainable development are terms that lead to various responses from managers, tourism planners, and environmental defenders, both skeptical and attentive.

According to Goeldner (2000), the concept of sustainable development is a development concept that we hear often and have been applied in various places. The application of the concept of sustainable development which can be said to be new is the insertion into the recognition equation the human race seeks economic, social and cultural development - and any efforts made to prevent such development on a strictly ideological basis are unlikely to succeed broad acceptance which if on an ongoing basis there is recognition that demographics, Consumptive and destructive economic, social and cultural growth cannot be carried out continuously without serious effects on the environment around us

\section{Concepts and strategies for regional development tourism destination}

A destination can be said to do tourism development if there are already tourist activities. To be able to increase the potential of its tourism, what needs to be done is to plan the development of tourism to be better than before. Three key principles in sustainability development (Mclntyre, 1993:10): Ecological Sustainability, that is to ensure that the development is done in accordance with the ecological processes, biology, and diversity of existing ecological resources. Social and Cultural Sustainability, that is to ensure that the development has made a positive impact on the lives of people around and according to the culture and values that apply to the society. Economic Sustainability, that is to ensure that 
the development is economically efficient and that the resources used can survive for future needs.

Design planning that can be done to prevent the reduction of native environmental land from excessive development, namely:

- Maximize land and building use and reduce development that can reduce green land

- Provide eco-friendly housing

- Encouraging the arrangement of urban areas good by way of building quality, road planning, and open space with good facilities

- Facilitate the activities of local people from going to work and other facilities.

- Make public transportation comfortable and feasible and make walking and cycling activities attractive

From the point of view of Gunn (1994), the tourism system is seen as a system that works functionally. Where this functional system is distinguished by Gunn into two parts, namely supply and demand. Gunn classifies the offer as a market where this market is influenced by people who have an interest in and the ability to travel so that various kinds of services are needed to receive tourists at tourist attractions so that tourist needs can be met. These services are then referred to as supplies. Gunn classified supplies into five components, namely attractions, transportation, information, promotions, and service facilities.

\section{Methods}

Survey Primer data collection with visual observation of "time budget method" Observation and photo media, secondary data collection techniques by means of finding the needs of the user's activities both visitors and tenants.

The "Place centred healthcare mapping" method is one of the ways to conduct the Behavioral Mapping (Sommer, 1986) in (Haryadi, 1995) where this method of observation is used to analyze the behavior of people or groups of people utilizing or pouring their behavior into certain conditions and places. If it is interpreted, this method is more concentrated in a more specific place both small and wide in this area of Ocarina located in the centre of Batam. Some problems in the area of Ocarina Batam City are:

a. Recreational facilities in the area are less interested in visitors due to the condition that many are damaged and poorly maintained

b. The location selling the tenants are less comfortable because of the weather and the sea breeze is hot and strong.

c. Lack of street furniture in sidewalk along the area so that the visitors less interested to walk along the area

Data collection method is done with visual observation that is observation at a certain time ("time budget Method") and photo media documentation. Time budget method is based on the assumption that weekend visitors mostly set aside time to relax both for themselves and with family and relationships especially for tourists and local visitors.

\section{Result and Discussion}

\subsection{Activities in and around Ocarina area}

Activities in the area of Ocarina and surrounding areas are generally residential (Avante, the Monde Signature, Monde Residence, Monde Bay, Costarina), shops, Minimart, offices (Pasir Putih shops, Trikarsa Ekualita shops, etc.), education (Mondial school) and the market at once foodcourt (Pasir Putih market). 
Activities of the Ocarina area and surrounding areas are divided into several parts, among others: (Source: Author, 2019)

\begin{tabular}{|c|l|c|c|}
\hline No. & \multicolumn{1}{|c|}{$\begin{array}{c}\text { Location of activity } \\
\text { perpetrators }\end{array}$} & $\begin{array}{c}\text { Activity time } \\
\text { Western Indonesian Time (WIT) }\end{array}$ & Perpetrators \\
\hline 1. & Housing activities & 24 hours & guest \& residents \\
\hline 2. & Commercial Activities & 07.00 WIT -18.00 WIT & seller \& buyers \\
\hline 3. & Office activities & 09.00 WIT -17.00 WIT & employee \& client \\
\hline 4. & Indomaret Minimarket & 24 hours & seller \& buyers \\
\hline 5. & Education & 07.00 WIT -17.00 WIT & teacher, student \& old man \\
\hline 6. & Market \& foodcourt & 07.00 WIT -17.00 WIT & seller \& buyers \\
\hline 7. & Areas of Ocarina & $\begin{array}{c}09.00 \text { WIT }-21.00 \text { WIT } \\
\text { (weekdays) }\end{array}$ & tenant \& visitors \\
& & $\begin{array}{c}07.00 \text { WIT }-22.00 \text { WIT } \\
\text { (weekend) }\end{array}$ & \\
\hline
\end{tabular}

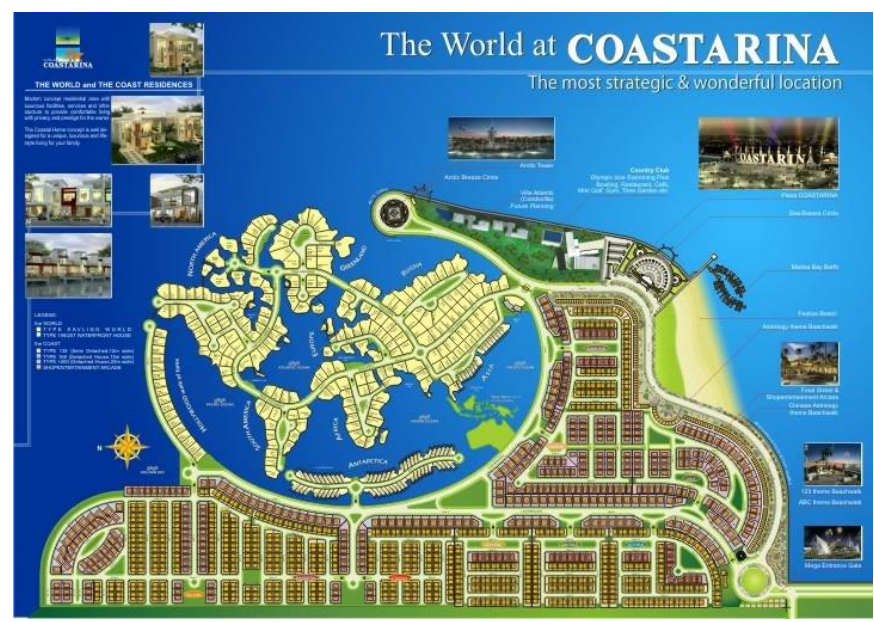

Picture 3.1. Masteplan Coastarina Area

Source: https://m.kaskus.co.id/thread/5134ab805a2acff40b000016/coastarina-palm-island-alaindonesia--palm-island-terbesar-didunial, 2018

Ocarina area, besides a tourist area is also a middle-up residential area with the concept of continents in the world by doing sea reclamation. The houses in Coastarina have the characteristics and concept of the building in accordance with the name of the form. Each continent connected by a bridge can be seen in the picture. 3.1.

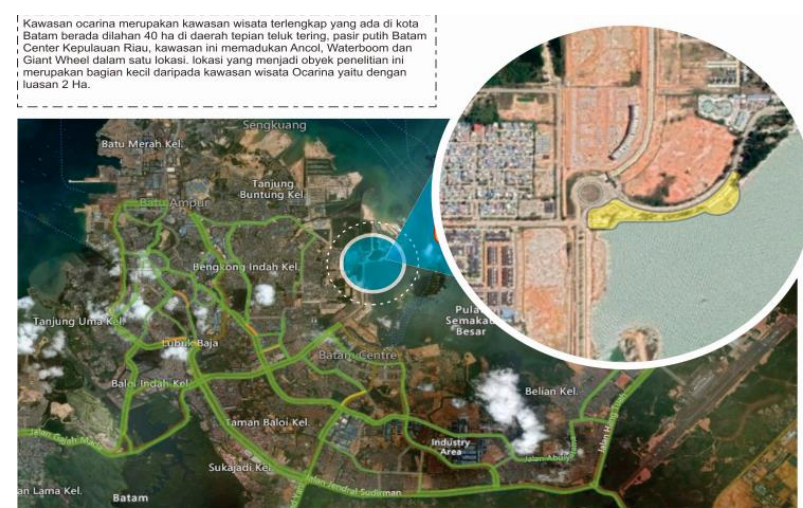

Picture 3.2. Map of Ocarina and around area

Source: Author, 2019 


\subsection{Activities in the Ocarina area}

Activities within the area of Ocarina on weekends and national holidays are relatively much more crowded than weekdays (Mondays to Fridays). Visitors activities and tenants are also relatively more on weekends and national holidays, among others in the morning around 06.00 WIB there are already visitors who come to exercise morning and at 07.00 WIB every Saturday and day week from the organizer held sports gymnastics activities along with inviting local instructors and tenants on weekdays usually open starting from 09.00 WIB until 18.00 WIB at the weekend open early around 07.00 WIB and Closes longer 22.00 WIB and also appears tenant-tenant which is open only on Saturdays and Sundays using the means of portable tents.

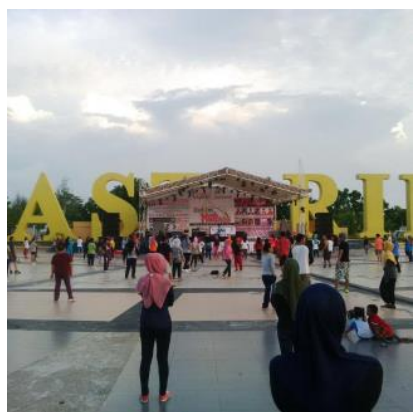

Picure 3.3. Joint Sports Activities Weekend Source:

https://www.facebook.com/1410978969168176/photos/ a.1410986639167409/1437101139889292/, 2016

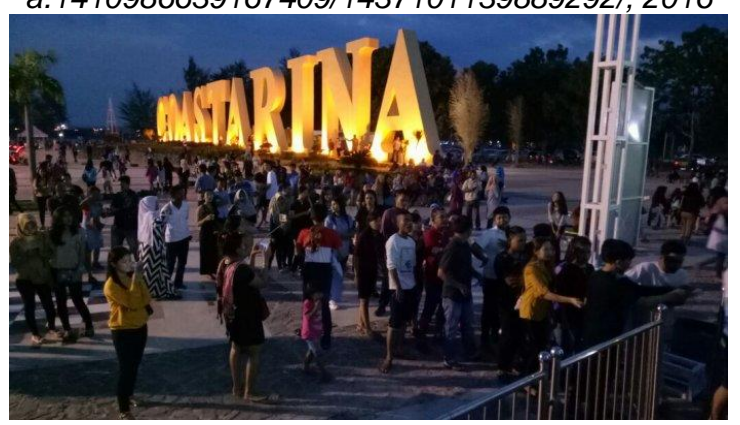

Picture 3.5. Ocarina Area on Saturday Source:

https://batam.tribunnews.com/2018/04/08/ocarina, 2018

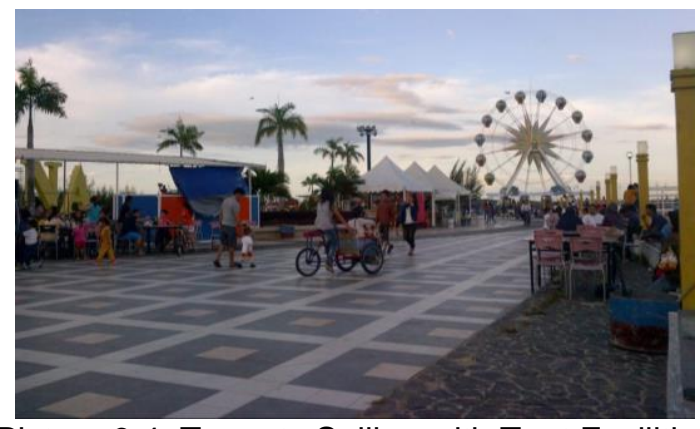

Picture 3.4. Tenants Selling with Tent Facilities Source: https://bintantravel.co.id/ocarina-batam, 2019

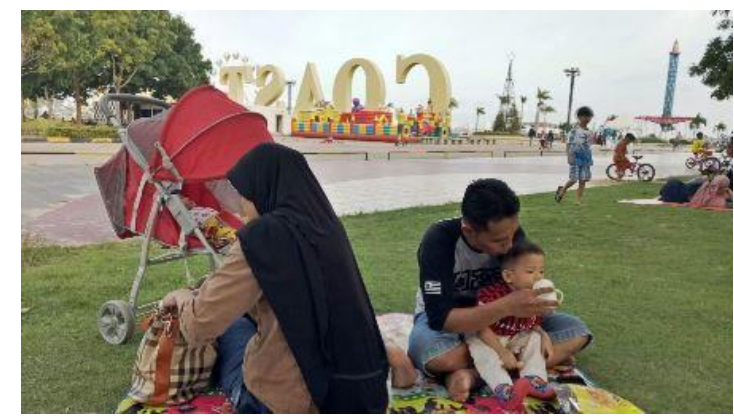

Picture 3.6. Visitors Activities in The Ocarina Area Source: https://menixnews.com/cara-asyik-nikmatiwisata-ocarina-batam-bersama-keluarga/, 2018

Road traffic in the Ocarina area is divided into 2 (two), namely: Vehicle lines where the vehicle lines within the Ocarina area are relatively safe and facilitated because the parking bags are available and can accommodate tourist buses and also the main road area is felt quite large \pm 20 meters, both two-wheeled vehicles and four-wheeled roads that cross the main road of the region. Walking trails (sidewalk), pedestrians are mostly used for leisure, cycling, rickshaw and roller-skis both adults and children visitors. 


\subsection{Area of Ocarina 2}

\subsubsection{Location Ocarina 2}

The area of Ocarina 2 is located in Batam City district, Batam City can be seen in the picture. 3.7 is a tourism area that is designed as a tourist destination in Batam city.
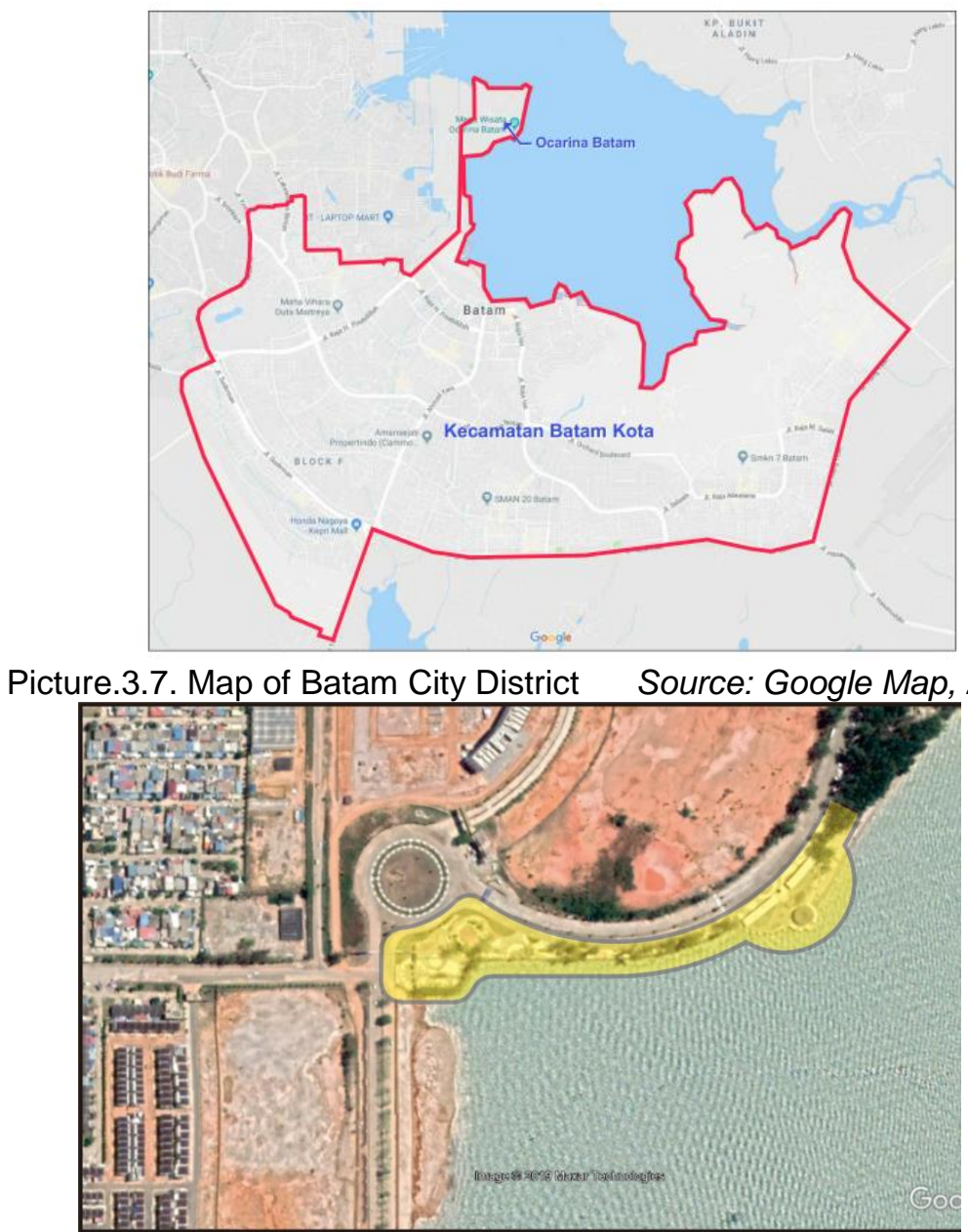

Picture.3.8.Location Ocarina 2

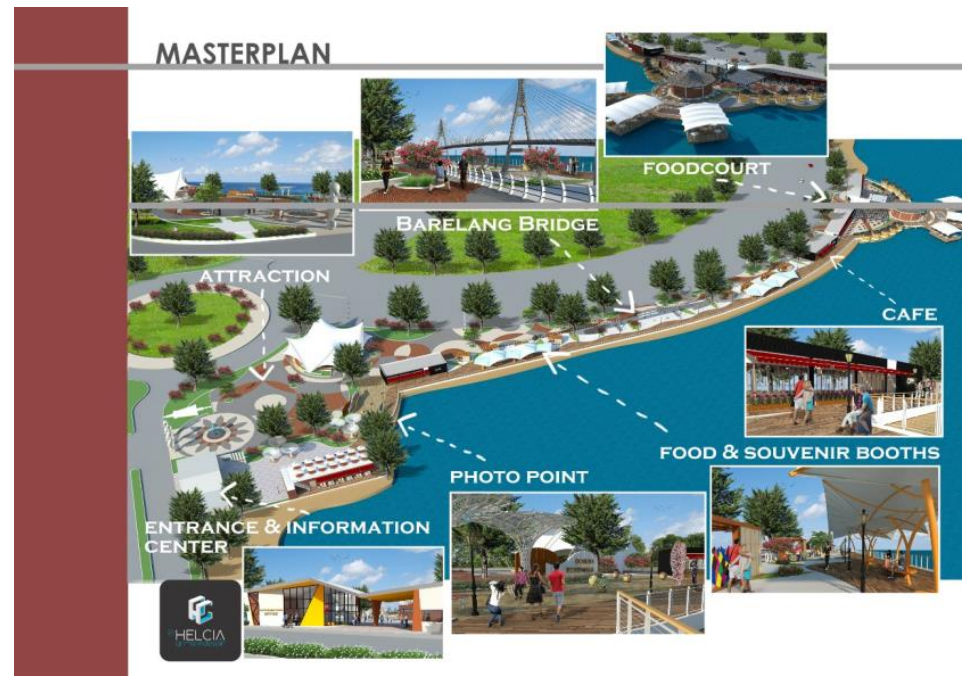

Picture 3.9. Master Plan Ocarina 2 
The area of Ocarina 2 fused with the Ocarina area can be seen in the picture. 3.8, the development by reclaiming the coastal area approximately 15 meters to the Pasir Putih beach.

\subsubsection{Zoning Ocarina 2}

Zoning Ocarina Phase 2 is divided into 3 (three) zones, namely:

(1) Entrance zone with modern building concept adjacent to information room, using glass material and bright paint color and atraction area is an inclusive concept where as a place that can accommodate the show/attractions of all ages, all genders special performances of Malay arts that want to be featured as a show for tourists who visit.

(2) Entertainment zone, this zone consist of atraction area, photo Point area, food and souvenir booths area. Atraction area is an inclusive concept where as a place that can accommodate the show/attractions of all ages, all genders special performances of Malay arts that want to be featured as a show for tourists who visit. Photo Point area in the form of visitor area for selfies, in this area there are miniature Barelang bridge and some photo points with the backdrop of the scenery around the area. For anticipate the visitors who are exhausted and want to take a break while looking at the sea view and greenery around the area, in the food and souvenir area booths area provided food stalls and soft drinks equipped with sitting furniture also there are cafes and souvenir stalls for the visitors.

(3) Transitional zone, this zone is a transitional zone of visitors coming from the area Ocarina 1 to the area Ocarina 2 and visitors coming from the area Ocarina 2 to the area Ocarina 1. This zone is in the form of foodcourt with the theme "Rumah Kelong" as well as a restaurant which is a concept of view where the visitors will enjoy the view of the offshore while enjoying the food and drinks that are ordered while resting.

\subsubsection{Ocarina 2 area with Sustainable Tourism concept}

Implementation of the sustainable tourism concept applied to the area of Ocarina Phase 2 includes:

(1) Ecological Sustainability, where the mangrove forest is maintained and maintained its existence, in addition to being a barrier as well as one of the habitat of marine ecosystems that exist around the area Ocarina region especially Ocarina Phase 2. Some tall plants and trees were also planted and grown to develop as one of the protectors of hot weather and hot breezes from the sea, thus giving comfort for the visitors who were in the location. As for the existing building has applied openings with windows so that the use of sunlight as a more optimal illumination and the wind that enters as a natural air circulation more maximized, using environmentally friendly building materials, as well as planting trees as a green, and the use of rainwater processed and accommodated as a plant sprinklers;

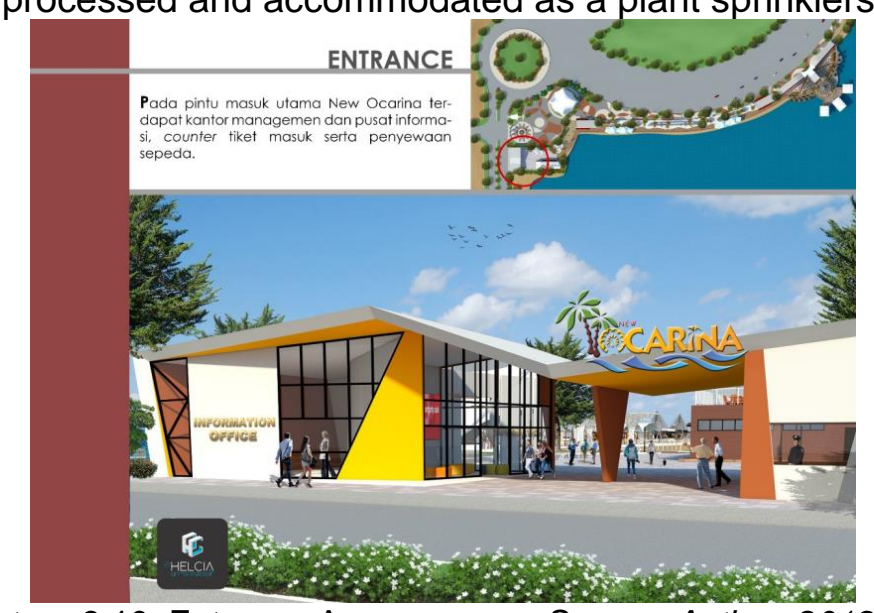

Picture 3.10. Entrance Area

Source: Author, 2019 


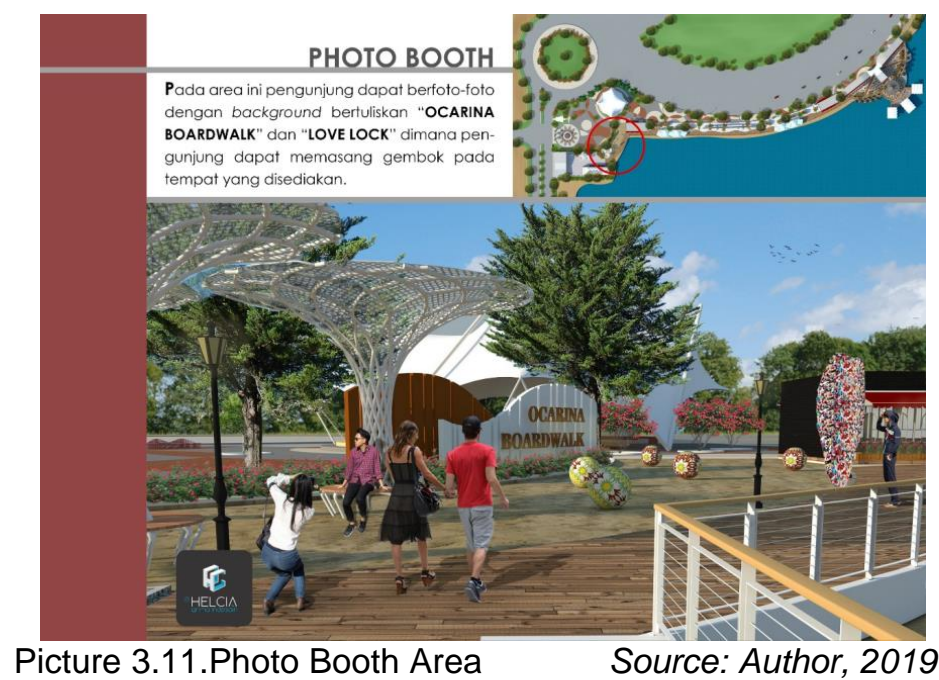

(2) Social and Cultural Sustainability, ocarina area Phase 2 is planned as mobilizer and revive the Ocarina area especially the Ocarina area of Phase 1 where the area of Ocarina Phase 1 experienced a decline in quality and its activities are increasingly diminished and deserted visitors. Malay culture is adopted and implemented in this area in the form of art and cultural performances and the provided the Malay nuance foodcourt "Rumah Kelong" is one way to preserve the Malay culture that characterizes the city of Batam in general and also in the building miniature from the bridge Barelang as one of the icons of Batam.

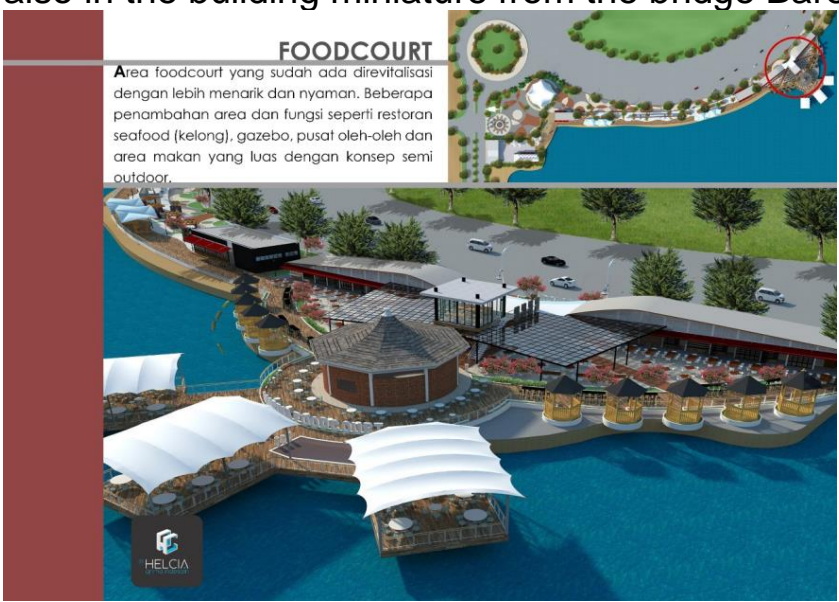

Picture.3.12.Foodcourt Area

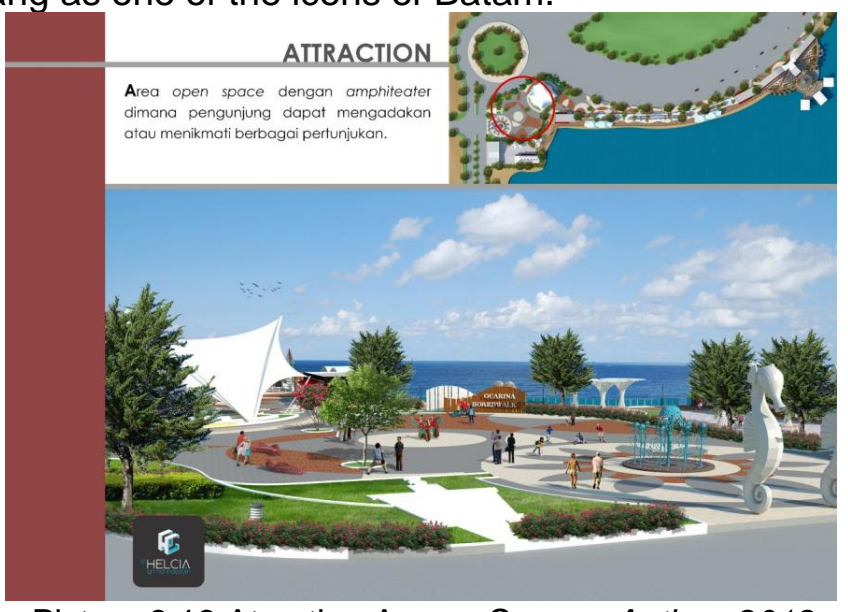

Picture.3.13.Atraction Area

Source: Author, 2019

Picture.3.14.Barelang Brigade

Source: Author, 2019 
3) Economic Sustainability, Ocarina area Phase 2 in its development consider material efficiency with the selection of materials that prioritize local and environmentally friendly materials, electricity energy using Solarcell system, the use of water by processing rainwater as a plant sprinklers. Faucet-water faucet using automatic sensor will be dead itself when not in use. In addition to the management of the venue is to empower fish traders, souvenirs, sellers of souvenirs and home industries vendors who are engaged in the culinary specialty of Batam by providing food and drinking areas for the visitors.
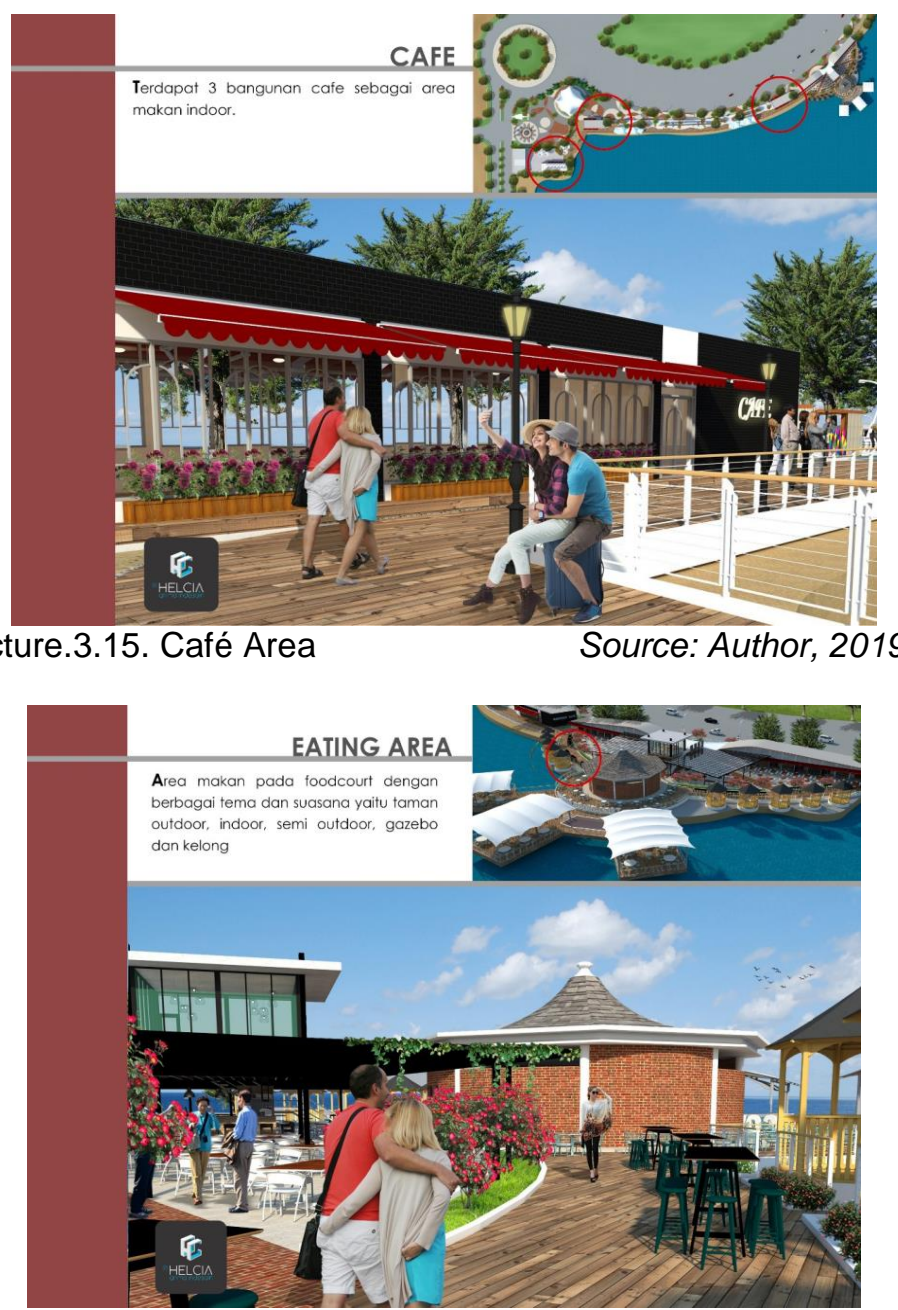

Picture 3.16.Eating Area

Source: Author, 2019

\section{Conclusion}

The concept of tourism area Ocarina 2 has been weighing and has implemented Suistanable City in the Ocarina 2 area planning such as; (1) Preservation is maintaining and maintaining existing plants; (2) education by providing learning for visitors to save the natural resources, especially water by giving an appeal in the toilets, by providing a trash can determine to give learning clean, healthy and disciplined, invite visitors to maintain the environment by treating the plants; 3) The economy is able to accommodate the work area for the residents of Batam, increasing tourist visits to Batam, upgrading regional income Batam City, revive the area of Ocarina particularly residential surrounding that was previously not developed and many abandoned by the owners. 


\section{Acknowledgments}

Author thanks to the lecturers of the Master of Architecture, Diponegoro University who always guide and give direction, the senior architects who have given advice and input to the design planning Ocarina 2, as well as college friends who always give encouragement so that the author can comply this journal.

\section{References}

Abdilah Fitra dan Leksmono, S Maharani. (2001). Pengembangan Kepariwisataan berkelanjutan, Jurnal IImu Pariwisata Vol.6, No. I. July 2001

Anom, I Putu. (2010), Pariwisata Berkelanjutan Dalam Pusaran Krisis Global, Denpasar : Udayana University Press.

Goeldner R, Ritchie B.R.J; McIntosh W.R. (2000), Tourism : Principles, Practices, Philosophies. Jon Willey \& Sons, Canada.

Gunn C. (1994), Tourism Planning; Basic, Concepts and Cases, Taylor and Francis, USA.

Lynch, Kevin. (1977). The Image of The City. Cambridge, Massachusetts, and London, England: The M.I.T. Press.

Setiawan, Haryadi. (2010). Architecture, Environment and Behavior: Introduction to Theory, Methodology and Application, Gadjah Mada University Press. 